\title{
Далингер В.А. \\ Результаты реализации идей Болонской декларации в российском математическом педагогическом образовании
}

Омский государственный педагогический университет

doi 10.18411/gq-31-03-2021-34

(Россия, Омск)

idsp sciencerussia-31-03-2021-34

\section{Аннотация}

В статье анализируются основные направления реализации Болонской декларации и показано, каким образом они реализованы в российском математическом педагогическом образовании; отмечены основные пути и средства подготовки учителей математики в педагогических вузах в современных условиях.

Ключевые слова: Болонская декларация, математическая подготовка студентов, модернизация процесса подготовки учителя математики.

\section{Abstract}

The article analyzes the main directions of the Bologna Declaration and shows how they are implemented in the Russian mathematical teacher education; highlighted the key ways and means of preparation of mathematics teachers in pedagogical institutes.

Keywords: Bologna Declaration, the mathematical training of students, the modernization process of preparation of mathematics teachers.

В сентябре 2003 г. в Берлине министр образования Российской Федерации поставил свою подпись под документом о присоединении России к Болонскому процессу.

Более чем 17-летнее участие России в Болонском процессе позволяет подвести некоторые итоги.

В России, как, впрочем, и во многих странах Европы, основной формой подготовки профессиональных кадров через систему высшего образования был специалитет. Переход российской системы высшего образования на двухуровневую систему (бакалавр-магистр) привел к ломке старых учебных планов и программ при отсутствии полноценной замены.

Упование на компетентностный подход, который в системе образования пришел на смену предметно знаниевому, вряд ли обеспечит те результаты образования, которые ожидают государство и общество. (До сих пор удивляюсь тому, как нашим учителям и преподавателям, не знавших таких слов как компетенция, компетентность, технология обучения и т.д., удалось выучить мое поколение (1950 год рождения)).

А.В. Шевкин замечает: «Реформируем, реформируем образование, а оно все не реформируется. Брестская крепость российского образования все не сдается. Реформаторам осталось одно: перекрыть ей приток боеспособных сил...» [12].

Уместно привести слова П.Я. Чаадаева: «На учебное дело в России может быть установлен совершенно особый взгляд, ему возможно дать национальную основу, в корне расходящейся с той, на которой оно зиждется в остальной Европе, ибо Россия развивалась во всех отношениях иначе, и ей выпало на долю особое предназначение в этом мире».

На международной научной конференции, проведенной в Великом Новгороде 48 декабря 2007 г., отмечалось: «... можно констатировать, что пока Болонский процесс принес России в основном разрушение, развеялись иллюзии, необоснованные надежды» [4].

В.П. Одинец по этому поводу отмечает: «Однако эта вина не самого процесса, а тех лиц, которые руководили и руководят его внедрением в России, не задумываясь о 
последствиях или не понимая их. Тем более что в самой Болонской декларации подчеркивается, что “... все ее положения установлены как меры добровольного процесса согласования, а не как жесткие юридические обязательства”» [13, с. 9].

Приведу еще один документ, который хотя и не имеет прямого отношения к Болонской декларации, но столь радикально повлиявший на принятие Россией решений, в том числе и в области образования. Имею в виду доклады Всемирного банка, которые одновременно с Болонской декларацией радикально влияли на образовательную политику России.

В первом докладе Всемирного банка «Россия: образование в переходный период» от 22 ноября 1994 г. № 13638-RUS высказано немало рекомендаций в адрес руководства России: «закрыть педагогические институты, закрыть профессиональные училища, ввести подушевое финансирование школ, исходя из уровня расходов на одного ученика и т.д.». в докладе высказано также мнение о «несправедливости и неэффективности экзаменационной системы».

В таком же духе составлены и другие доклады, например, доклад «Обновление образования в России (региональный уровень)» под № 18666-КН.

Авторы докладов не сказали о том, как следует сделать, например, экзаменационную систему эффективной, но именно с этого момента (1999 г.) пришла в российское образование идея Единого государственного экзамена (ЕГЭ), которая породила страстные споры. ЕГЭ перевели в режим долговременного «эксперимента», и, как верно замечает И.М. Ильинский [11], эксперимент был обречен «на сокрушительный успех», поскольку экспериментаторами были носители этой идеи... «Зеленый» светофор для ЕГЭ оказался открыт, и 2009 год стал годом тотальной егэизации российского образования.

Отметим мнения некоторых учителей и ученых о проводимом в настоящее время ЕГЭ.

А.И. Кузьмичев отмечает: «Каток ЕГЭ начисто сравнял “бугорки и буераки” ... ЕГЭ не только не разрешил проблемы и противоречия нашей школы, а еще больше выпятил их и привнес свои новые, специфические» [11, с. 5].

Такого же мнения В.А. Черкасов: «Результаты внедрения ЕГЭ в его нынешнем виде в основном отрицательные: проблема коррупции не решена; процедура не способствует совершенствованию преподаванию; уровень знаний учащихся падает; результаты экзамена недостоверны и т.д. ... попытка по результатам ЕГЭ оценить сложнейший процесс обучения и воспитания - это все-таки абсурд» [19, с. 8-9].

В.А. Рыжик подчеркивает: «ЕГЭ - это мина замедленного действия» $[14, \mathrm{c}$. 64]. Он указывает на следующие недостатки ЕГЭ: не соответствует ценностям математического образования; не соответствует национальным традициям математического образования; структурно нелеп; провоцирует учителя на несвойственную ему деятельность; создает иллюзию объективности.

В марте 2010 г. на конференции министров образования европейских стран в Будапеште и Вене [20] Россия объявила, что четыре цели, поставленные в Болонской декларации 1999 г., за годы присоединения к Болонскому процессу, Россией полностью выполнены [1].

Мой, более чем 40-летний опыт обучения математике в школе и вузе, позволяет сделать некоторые комментарии к утверждениям о выполнении Россией четырех целей Болонской декларации.

По поводу первой цели. До сентября 2008 г. действия властей на Федеральном и региональном уровнях способствовали расширению доступа к высшему образованию. Но, следует заметить, что это осуществлялось в основном за счет платного образования. Но с сентября 2008 г. политика властей была направлена на ограничение доступа к высшему образованию (сокращение числа приема студентов на бюджетные 
места; закрытие ряда небольших вузов и филиалов (даже там, где они были градообразующими) и др.).

По поводу второй цели. Приведу лишь обоснованные мнения ученых и учителей. Ректор МГУ, академик В.А. Садовничий заявил на сентябрьском 2009 г. заседании Российского съезда ректоров, что примерно 60\% процентов первокурсников двух факультетов «провалили» контрольную по математике единого государственного экзамена (факультеты математики и вычислительной математики). И это в самом элитном российском вузе! А что в других вузах? Опытный преподаватель высшей математики из НИИ МЭИ Е.П. Богомолова отмечает: «Пока на бумаге планка математического образования будущих бакалавров и магистров поднимается все выше, в реальности преподаватели вынуждены опускать планку требований к студентам все ниже и ниже» $[2$, с. 3$]$.

Заслуживает внимания высказывание учителя математики Д.Д.Гущина, о том, что наше «лучшее физико-математическое образование» уже настолько не лучшее, что даже уже и не образование.

Одной из причин, отмеченного факта, является резкое сокращение в новых учебных планах подготовки бакалавров направления «Педагогическое образование», профиль «Математическое образование» [15] числа часов на изучение математических дисциплин, что приводит к тому, что у студентов не формируются ни «пресловутые» предметные знания, умения и навыки, ни провозглашенные современными стандартами компетенции.

Надо заметить, что в стандартах общего образования [16] также акцент сделан на «обеспечение преимущественно образовательной и общекультурной подготовки». Отсюда и порядок расположения требований к результатам освоения основной образовательной программы: личностные, метапредметные и лишь на последнем месте предметные результаты.

С.Н. Бычков замечает: «... заострение внимания на метапредметных и личностных результатах, выдвижение их на первый план излишне: математика сама своим собственным содержанием позволяет достигать всего сразу, следуя собственной двухтысячелетней традиции» [5, с. 58].

Анализ содержания ФГОС ВПО по направлению подготовки 050100 «Педагогическое образование» (квалификация (степень) «бакалавр») [15] показывает, что в них отсутствует предметная составляющая. В нем нет ни слова о том, что учитель-предметник должен знать свой предмет хотя бы в объеме школьного курса. Обращает на себя внимание и тот факт, что в новых актуализированных образовательных стандартах (их раньше называли «3+») [17] среди компетенций, закрепленных за государственной итоговой аттестацией, нет ни одной, которая проверяла бы предметную подготовку выпускника.

О состоянии российского математического образования читатель найдет материал в наших публикациях $[6,7,8,9]$ и в работе [18].

Для полноценного достижения третьей цели Болонской декларации нужна хорошая финансовая база вузов, которая сегодня не соответствует предъявляемым требованиям.

Достижению цели успешного трудоустройства выпускников вуза (четвертая цель) мешают многие факторы: не работают многие производственные предприятия, куда могли бы пойти работать выпускники вузов; немотивированный выбор студентами сферы профессиональной деятельности на этапе поступления в вуз; заниженная оплата труда специалистов в той или иной сфере деятельности и др.

Основными направлениями совершенствования (а вернее спасения) российской системы математического образования могут служить: отказ от двухуровневой (бакалавриат и магистратура) системы подготовки учителя математики и возращение к 
подготовке учителя математики через специалитет (смогли же медицинские работники отстоять свое право готовить медицинские кадры через специалитет!); устранение тенденции резкого сокращения числа часов на предметную и методическую подготовку учителей математики.

$$
\text { *** }
$$

1. Белов, В.А., Энтин, М.Л., Гладков, Г.И. и др. Болонский процесс и его значение для России / В.А. Белов, М.Л. Энтин, Г.И. Гладков [и др.] // Российско-европейский центр экономической политики / Под ред. К. Пурсиайнена, С.А. Медведева. - М.: РЕЦЭП, приложение основных документов Болонского процесса, 2005 г. - 176 c.

2. Богомолова, Е.П. Диагноз: математически малограмотный / Е.П. Богомолова // Математика в школе. - 2014. - № 4. - С. 3-9.

3. Болонский процесс в математическом и естественнонаучном педагогическом образовании: тенденции, перспективы, проблемы. - Петрозаводск: Изд-во КГПУ, 2005. - 442 с.

4. Болонский процесс в России и Европе: опыт, решение, перспективы // Материалы Международной научной конференции, 4-8 декабря 2007 г. / Под ред. Е.А. Бондаренко. - Великий Новгород: Издво НовГУ, 2008 . -63 с.

5. Бычков, С.Н. Чему и как учить на уроках математики стабильно неуспевающих школьников / С.Н. Бычков // Математическое образование сегодня и завтра: материалы Международной конференции, Москва, 28-29 ноября 2013 / Сост. Атанасян С.Л. - М.: Изд-во ГАОУ ВПО «Московский институт открытого образования», 2014. - С 57-60.

6. Далингер, В.А. Единый государственный экзамен по математике: анализ, проблемы, поиск / В.А. Далингер // Математика и информатика: наука и образование: Межвузовский сборник научных трудов. Ежегодник. Вып. 7. - Омск: Изд-во ОмГПУ, 2008. - С 89-100.

7. Далингер, В.А. Так ли уж безобидна многоуровневая система высшего образования в плане подготовки специалистов? / В.А. Далингер // Фундаментальные исследования. - № 11 (часть 5). 2012. - М: Изд-во Академия Естествознания, 2012. - С. 1095-1098.

8. Далингер, В.А. Причины математической малограмотности российских школьников / В.А. Далингер // Педагогика: семья - школа - общество: монография / под общей ред. проф. О.И. Кирикова. - Книга 31. - Москва: Наука: информ; Воронеж: ВГПУ, 2014. - С 72-82.

9. Далингер, В.А. Российское математическое образование: проблемы и перспективы развития: материалы XI Всероссийской научно-практической конференции «Проблемы развития математического образования», 5-6 ноября 2013 г. Армавир / В.А. Далингер // Тенденции и проблемы развития математического образования: научно-практический сборник. Вып. 11 / науч. ред. Н.Г. Дендеберя, С.Г. Манвелов. - Армавир: РИО АГПА, 2013. - С 3-8.

10. Ильинский, И.М. Эти странные российские реформы... / И.М. Ильинский [Электронный ресурс]. URL::http://netreforme.org/news/igor-ilinskiy-eti-strannyie-rossiyskie-reformyi/ .

11. Кузьмичев, А.И. Реформа для проформы (по следам наших публикаций) / А.И. Кузьмичев // Математика в школе. - 2014. - № 7. - С. 3-7.

12. «Неугомонные реформаторы» и другие новости (обзор Интернет-ресурсов) // Математика в школе. - 2004. - № 3. - C. 14-16.

13. Одинец, В.П. К 10-летию Болонского процесса в России / В.П. Одинец // Вестник Московского университета: научный журнал. - 2014. - №1 (январь-март). - Серия 20: Педагогическое образование. - М.: Изд-во Московского университета. - С. 3-10.

14. Рыжик, В.И. ЕГЭ ... Как много в этом звуке... / В.И. Рыжик // Математика в школе. - 2011. - № 9. - C. 58-64.

15. Федеральный государственный образовательный стандарт высшего профессионального образования по направлению подготовки 050100 «Педагогическое образования» (квалификация (степень) «бакалавр») [Электронный ресурc]. - URL:http://минобрнауки.pф/документы/1908.

16. Федеральный государственный образовательный стандарт общего образования. - М., 2008. - 21 с.

17. ФГОС-3 плюс 2013: проект. - URL: http://window.edu.ru/recommended/37

18. Шашкина, М.Б., Табинова, О.А. О качестве математической подготовки в школе и вузе [Электронное издание] / М.Б. Шашкина, О.А. Табинова // Математика в школе. - 2014. - № 1.

19. Черкасов, В.А. Оценивают по результатам, а не по намерениям / В.А. Черкасов // Математика в школе. - 2014. - № 7. - С. 7-10.

20. Budapest-Vienna Declaration on the European Higher Education Area // News archive-2010. 